\title{
Design and Synthesis of Novel Anti-metastatic Hypoxic Cytotoxin TX-2137 Targeting AKT Kinase
}

\author{
IKKYU SHIBA $^{1}$, RISA KOUZAKI ${ }^{1}$, HISATSUGU YAMADA ${ }^{2}$, YOSHIO ENDO $^{3}$, TAKAHISA TAKINO $^{3,4}$, \\ HIROSHI SATO $^{3}$, KEIKO KITAZATO ${ }^{5}$, TERUYOSHI KAGEJI ${ }^{5}$, SHINJI NAGAHIRO ${ }^{5}$ and YOSHIHIRO UTO $^{2}$ \\ ${ }^{1}$ Graduate School of Advanced Technology and Science, Tokushima University, Tokushima, Japan; \\ ${ }^{2}$ Institute of Technology, Industrial and Social Sciences, and \\ ${ }^{5}$ Institute of Biomedical Sciences, Tokushima University Graduate School, Tokushima, Japan; \\ ${ }^{3}$ Central Research Resource Branch, Cancer Research Institute, Kanazawa University, Kanazawa, Japan; \\ ${ }^{4}$ Institute of Liberal Arts and Science, Kanazawa University, Kanazawa, Japan
}

\begin{abstract}
Background: The hypoxic microenvironment plays a crucial role in the malignant progression of tumor cells. Moreover, AKT, a serine/threonine kinase, is activated by various extracellular growth factors and is important for cell growth, survival, and motility of leukocytes, fibroblasts, endothelial cells, and tumor cells. Therefore, we aimed to design an anti-metastatic hypoxic cytotoxin which has inhibitory effects on AKT. Results: TX-2137 was designed and synthesized based on the structural similarity of a preexisting AKT1/2 kinase inhibitor and a hypoxic cytotoxin tirapazamine. TX-2137 effectively reduced the expression of phosphorylated $A K T$ and matrix metalloproteinase 9 (MMP9) and showed strong inhibition of the proliferation of B16-F10, HT-1080, and MKN-45 cells. In addition, TX-2137 exhibited hypoxiaselective cytotoxicity towards A549 cells and inhibited liver metastasis of B16-F10 cells in a xenograft chick embryo model in the same way as doxorubicin. Conclusion: TX-2137 may be a potent lead compound in the development of a novel antimetastatic AKT kinase inhibitor.
\end{abstract}

Hypoxia, a characteristic feature of many solid tumors, leads to chemoresistance, radioresistance, increased angiogenesis, vasculogenesis, invasion, metastasis, resistance cell death, genomic instability, and changes in metabolism (1-5). Tirapazamine (SR 4233) is a well-known drug that specifically exerts toxicity under such hypoxic conditions through the release of free radicals $(6,7)$. These free radicals, formed by

Correspondence to: Dr. Yoshihiro Uto, Institute of Technology, Industrial and Social Sciences, Tokushima University Graduate School, Tokushima University, 2-1 Minamijosanjima-cho, Tokushima, 770-8506, Japan. Tel/Fax: +81 886567514, e-mail: uto.yoshihiro@tokushima-u.ac.jp

Key Words: AKT, hypoxic cytotoxin, anti-metastatic agent, TX-2137. natural decay of oxidized hydroxyl radical $\left(\mathrm{OH}^{\circ}\right)$ or benzotriazinyl radical (BTZ*) following one-electron reduction of tirapazamine by NADPH-cytochrome 450 reductase, induce cytotoxicity by causing double-strand breakage of DNA (8). Tirapazamine is a prodrug that has advanced to phase III clinical trials $(9,10)$. A phase III clinical trial was conducted in patients with head and neck cancer with tirapazamine in combination with radiation or chemoradiation with cisplatin, but no significant differences in the 2-year overall survival and failure-free survival were reported when compared to patients treated with radiation plus cisplatin (11). However, the tirapazamine combination treatment with radiation plus cisplatin was effective when compared to chemoradiation with cisplatin and fluorouracil (9). The tirapazamine combination treatment is still feasible and its clinical trials are ongoing in patients with locally advanced cervical cancer and oropharyngeal cancer (NCT00094081, NCT00262821).

The phosphoinositide 3-kinase (PI3K)/AKT signal pathway is the most frequently activated signal transduction pathway in human cancer (12) and plays an important role in cell-cycle regulation, survival, migration, invasion, and metastasis of cancer cells (13-15). In addition, Young et al. reported that activated AKT accumulates in mitochondria under hypoxic conditions; changes various cellular responses and biological processes such as tumor metabolism to glycolytic system, apoptosis, and resistance to autophagy; alleviates oxidative stress, and maintains the growth of tumor cells faced with severe hypoxia (16). In this study, we, therefore, designed and synthesized an anti-metastatic hypoxic cytotoxin with AKT-inhibitory activity.

\section{Materials and Methods}

Materials. Nuclear magnetic resonance (NMR) ${ }^{1} \mathrm{H}$ spectra were obtained using a JNM-EX400 spectrometer (Jeol, Tokyo, Japan) at $400 \mathrm{MHz}$. Solvents were evaporated under reduced pressure on a rotary evaporator. Thin-layer chromatography was performed on 
<smiles>Nc1n[n+]([O-])c2ccccc2[n+]1[O-]</smiles>

Tirapazamine<smiles>[O-][n+]1nc(Nc2ccc(O)cc2)[n+]([O-])c2ccccc21</smiles>

AKT1/2 inhibitor

TX-2137

$\begin{array}{ll}\text { LUMO }(\mathrm{eV}) & -1.4041 \\ \text { HOMO }(\mathrm{eV}) & -8.1342\end{array}$

$-0.9709$

$-1.5026$

$-8.7148$

$-7.9846$

Figure 1. Design of TX-2137 based on tirapazamine and AKT1/2 inhibitor.

glass-backed silica gels (Merck 60 F254; Merck Japan, Tokyo, Japan) and components were visualized using ultraviolet (UV) light. Column chromatography was performed using a silica gel $(60 \mathrm{~N}$, spherical neutral; 40-50 $\mu \mathrm{m}$; KANTO Chemical, Tokyo Japan). The molecular orbital structure was calculated by WinMOPAC 3.0 (PM3, Fujitsu, Kawasaki, Japan).

Cell culture. B16-F10 mouse melanoma cells (kindly provided by Dr. Tsuruo, Tokyo University, Tokyo, Japan) and A549 human lung carcinoma cells (supplied by Dr. Kondo, Kyoto University, Kyoto, Japan) were maintained in Dulbecco's modified Eagle's medium (DMEM) (Wako Pure Chemical, Osaka, Japan), while HT-1080 human sarcoma cells (purchased from American type culture collection, Manassas, VA, USA) were cultured in Eagle's minimum essential medium (EMEM) (Wako Pure Chemical). MKN-45 human adenocarcinoma cells (Dr. Suzuki, Fukushima Medical College, Fukushima, Japan) and U87MG human neuronal glioblastoma cells (American Type Culture Collection Manassas, VA, USA) were maintained in RPMI-1640 medium (Wako Pure Chemical). All media were supplemented with $10 \%$ fetal bovine serum and cells were cultured in a humidified atmosphere of $5 \%$ $\mathrm{CO}_{2}$ at $37^{\circ} \mathrm{C}$. Hypoxic culture was performed in a humidified atmosphere of $0.1 \% \mathrm{O}_{2}$ at $37^{\circ} \mathrm{C}$ using an AnaeroPack (Mitsubishi Gas Chemical, Tokyo, Japan).

Synthesis of 3-chloro-1,2,4-benzotriazine 1-oxide. 2-Nitroaniline (10 g, $72.4 \mathrm{mmol}$; Sigma-Aldrich Japan, Tokyo, Japan) and cyanamide (6.0 g, $144.8 \mathrm{mmol}$; Tokyo Chemical, Tokyo, Japan) were melted at $100^{\circ} \mathrm{C}$. Thereafter, $36 \% \mathrm{HCl}(40 \mathrm{ml}$; Wako Pure Chemical) was slowly added and the mixture was stirred at $100^{\circ} \mathrm{C}$ for $2 \mathrm{~h}$ then the solution was cooled to room temperature. To this mixture, $7.5 \mathrm{M}$ $\mathrm{NaOH}$ (200 ml; Wako Pure Chemical) was slowly added and stirred at $100^{\circ} \mathrm{C}$ for $2.5 \mathrm{~h}$. Finally, the solution was cooled to room temperature and water $(200 \mathrm{ml})$ was added and a substance precipitated from the solution was filtered with filter paper to yield compound 1 (3-amino-1,2,4-benzotriazine 1-oxide) as a yellow solid (17). 3-Amino-1,2,4-benzotriazine 1-oxide was dissolved in trifluoroacetic acid $\left(60 \mathrm{ml}\right.$; Wako Pure Chemical) at $5^{\circ} \mathrm{C}$ and sodium nitrite (4.8 g, 71.4 mmol; Tokyo Chemical, Tokyo, Japan) was added. The solution was stirred at room temperature for $2 \mathrm{~h}$ and was added dropwise to ice/water. The precipitate was filtered, washed with water, and dried. The solid produced (compound 2; 3-hydroxy-1,2,4- benzotriazine 1-oxide) was suspended in phosphoryl chloride $(27 \mathrm{ml}$; Wako Pure Chemical) and $N, N$-dimethylformamide $(5 \mathrm{ml}$; Wako Pure Chemical) and stirred at $100^{\circ} \mathrm{C}$ for $1 \mathrm{~h}$. Once cooled, the solution was added dropwise to ice/water, the precipitate was filtered, washed with water, and dried. The precipitates were purified by silica-gel column chromatography with dichloromethane $\left(\mathrm{CH}_{2} \mathrm{Cl}_{2}\right)$ to give compound 3 (3-chloro-1,2,4-benzotriazine 1-oxide) (1.9 g, 14.8\% yield) (18).

Synthesis of TX-2137. 4-Aminophenol (1.0 g, $9.2 \mathrm{mmol}$; Tokyo Chemical) and imidazole (1.2 g, $18.3 \mathrm{mmol}$; Tokyo Chemical) were suspended in $\mathrm{CH}_{2} \mathrm{Cl}_{2}$ under a nitrogen atmosphere. tertButylchlorodimethylsilane ( $2.1 \mathrm{~g}, 13.7 \mathrm{mmol}$; Tokyo Chemical) was added and the solution was stirred at room temperature for $1 \mathrm{~h}$, poured into saturated $\mathrm{NaCl}$ solution and extracted with $\mathrm{CH}_{2} \mathrm{Cl}_{2}$. The organic layer was evaporated to give compound $4(1.5 \mathrm{~g}, 73.1 \%$ yield). Next, compound 4 (0.25 g, $1.1 \mathrm{mmol})$ was dissolved in $\mathrm{CH}_{2} \mathrm{Cl}_{2}$. Triethylamine $(156 \mu \mathrm{l}, 1.1 \mathrm{mmol}$; Wako Pure Chemical) and 3-chloro-1,2,4-benzotriazine 1-oxide $(0.1 \mathrm{~g}, 0.6 \mathrm{mmol})$ were added and the solution was stirred at room temperature for $2 \mathrm{~h}$, poured into water and extracted with $\mathrm{CH}_{2} \mathrm{Cl}_{2}$. The organic layer was evaporated and purified by silica-gel column chromatography with $\mathrm{CH}_{2} \mathrm{Cl}_{2}$ to give compound 5 ( $0.17 \mathrm{~g}, 84.1 \%$ yield). Next, compound $5(0.1 \mathrm{~g}, 0.27 \mathrm{mmol})$ and $\mathrm{NaHCO}_{3}(0.045 \mathrm{~g}, 0.54 \mathrm{mmol}$; Wako Pure Chemical) were dissolved in $\mathrm{CH}_{2} \mathrm{Cl}_{2} . m$-Chloroperoxybenzoic acid (m-CPBA) (0.093 g, $0.54 \mathrm{mmol}$; Tokyo Chemical) was added and the mixture stirred at room temperature for $24 \mathrm{~h}$. The solution was collected using a filter paper, the filtrate was evaporated and the residue was purified by silica-gel column chromatography with ethyl acetate (EtOAc) and EtOAc/methanol $(\mathrm{MeOH})$, forming compound 6 (0.062 g, 54.9\% yield). Finally, compound 6 (0.61 g, $1.6 \mathrm{mmol}$ ) was dissolved in tetrahydrofuran at $5^{\circ} \mathrm{C}$ and $1.0 \mathrm{M}$ of tetrabutylammonium fluoride solution $(3.2 \mathrm{ml}, 3.2 \mathrm{mmol}$; SigmaAldrich Japan) was added. The solution was stirred at room temperature for $5 \mathrm{~min}$, solvents were evaporated and the residue was purified by silica-gel column chromatography with $10 \%$ $\mathrm{MeOH} /$ EtOAc to obtain compound 7 (TX-2137) (0.37 g, 84.7\% yield) in the form of a purple powder; ${ }^{1} \mathrm{H}$ NMR $\left[\left(\mathrm{CD}_{3}\right)_{2} \mathrm{SO}\right] \delta 9.96$ (s, 1H, PhOH), $9.41(\mathrm{~s}, 1 \mathrm{H}, \mathrm{PhNH}), 8.22(\mathrm{t}, \mathrm{J}=8.5 \mathrm{~Hz}, 2 \mathrm{H}), 7.97(\mathrm{td}$, $\mathrm{J}=7.8,1.4 \mathrm{~Hz}, 1 \mathrm{H}), 7.61(\mathrm{td}, \mathrm{J}=7.8,1.4 \mathrm{~Hz}, 1 \mathrm{H}), 7.38(\mathrm{~d}, \mathrm{~J}=8.7 \mathrm{~Hz}$, $2 \mathrm{H}), 6.79$ (d, J=8.7 Hz, 2H); MS (EI) m/z $270\left(\mathrm{M}^{+}, 13\right), 254$ (68), 238 (56), 210 (100); Anal. calcd for $\mathrm{C}_{13} \mathrm{H}_{10} \mathrm{~N}_{4} \mathrm{O}_{3}$ : C, 57.78; H, 3.73; N 20.73. Found C, 57.56; H, 3.76; N, 20.75. 

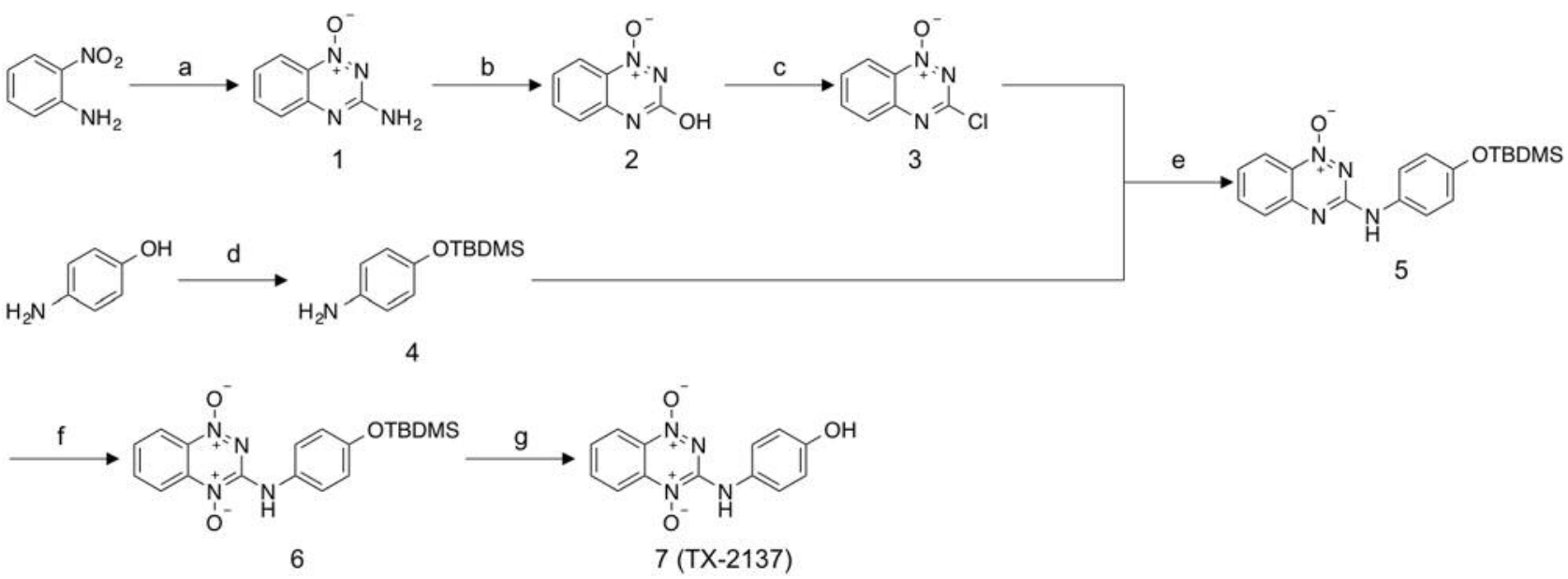

Figure 2. Synthesis of the TX-2137. Reagents: a: Cyanamide, $36 \% \mathrm{HCl}, 7.5 \mathrm{M} \mathrm{NaOH} ; b$ : Trifluoroacetic acid, sodium nitrite; $c$ : phosphoryl chloride, $\mathrm{N}, \mathrm{N}$-dimethylformamide; $d$ : tert-butylchlorodimethylsilane, imidazole, $\mathrm{CH}_{2} \mathrm{Cl}_{2}$; e: triethylamine, $\mathrm{CH}_{2} \mathrm{Cl}_{2} ; \mathrm{f}: \mathrm{m}$-chloroperoxybenzoic acid, $\mathrm{NaHCO}$, $\mathrm{CH}_{2} \mathrm{Cl}_{2} ; \mathrm{g}: 1.0 \mathrm{M}$ of tetrabutylammonium fluoride solution, tetrahydrofuran.

In vitro WST-8 assay to evaluate the effect of TX-2137 on cell proliferation. In vitro cell proliferation was examined using a colorimetric assay with Cell Counting Kit-8 (Dojindo Laboratories, Kumamoto, Japan) according to the manufacturer's instructions. Briefly, B16-F10, HT-1080 and MKN-45 cells were seeded at a density of $5 \times 10^{3}$ cells/well in a 96-well plate and TX-2137, dissolved in dimethyl sulfoxide, was added to the culture medium at concentrations between $0.1-100 \mu \mathrm{M}$. After $72 \mathrm{~h}$ incubation, the medium was replaced with fresh medium containing the WST-8 reagent. After $3 \mathrm{~h}$, the absorbance in each well was determined at $450 \mathrm{~nm}$ (with a reference wavelength of $620 \mathrm{~nm}$ ) using an ImmunoMini NJ-2300 microplate spectrophotometer (BioTec, Tokyo, Japan, Tokyo, Japan). The percentage of cell growth inhibition was calculated by applying the following formula: $\%$ of cell growth inhibition $=(1-[\mathrm{T} / \mathrm{C}]) \times 100$, where $\mathrm{C}$ and $\mathrm{T}$ were the mean absorbances of the control group and treated group, respectively. The $50 \%$ inhibitory concentration $\left(\mathrm{IC}_{50}\right)$ value was measured graphically from the dose-response curve with at least three drug concentration points.

In vitro hypoxia-selective cytotoxicity of TX-2137 using WST-1 assay. A549 cells were seeded in two 96-well plates at a density of $3 \times 10^{3}$ cells/well and incubation for $24 \mathrm{~h}$. After $24 \mathrm{~h}$, TX-2137 was added at the final concentrations of 0.1 to $30 \mu \mathrm{M}$ and each plate was incubated either normoxic $\left(21 \% \mathrm{O}_{2}\right)$ or hypoxic $\left(\begin{array}{lll}0.1 \% & \mathrm{O}_{2}\end{array}\right)$ conditions for $24 \mathrm{~h}$. After $24 \mathrm{~h}$, each well was washed with $1 \times \mathrm{PBS}$ and fresh medium containing the WST-1 reagent (Wako Pure Chemical) was added. The absorbance was measured at a wavelength of $450 \mathrm{~nm}$ using a Tecan Infinite M200 microplate reader (Tecan, Männedorf, Switzerland).

AKT inhibition by TX-2137 by western blot analysis on U87MG cells. The harvested cells were homogenized in RIPA buffer (Thermo Scientific, IL, USA) supplemented with protease inhibitors (cOmplete ${ }^{\mathrm{TM}}$, Mini, EDTA-free ${ }^{\circledR}$, Roche Applied Science Tokyo, Japan). After $5 \mathrm{~min}$ of centrifugation at $13,000 \times \mathrm{g}$, the protein
Table I. Cell proliferation inhibitory activity (A) and hypoxic cytotoxicity (B) of TX-2137.

A

\begin{tabular}{|c|c|c|c|c|}
\hline \multirow[t]{2}{*}{ Compound } & \multicolumn{4}{|c|}{$\mathrm{IC}_{50}(\mu \mathrm{M})$} \\
\hline & B16-F1C & HT & & MKN-45 \\
\hline TX-2137 & 3.7 & & & 1.8 \\
\hline \multicolumn{5}{|l|}{ B } \\
\hline \multirow[t]{2}{*}{ Compound } & \multicolumn{2}{|c|}{$\mathrm{IC}_{50}(\mu \mathrm{M}) \mathrm{A} 549$} & \multirow{2}{*}{\multicolumn{2}{|c|}{$\begin{array}{c}\text { Hypoxic selectivity, } \\
\text { normoxia/hypoxia }\end{array}$}} \\
\hline & Normoxia & Hypoxia & & \\
\hline TX-2137 & 9.2 & 2.2 & & 4.2 \\
\hline Tirapazamine & 94.4 & 7.2 & & 13.1 \\
\hline
\end{tabular}

concentration in the supernatant was assayed with $\mathrm{BCA}$ reagent (PIERCE, Tokyo, Japan). After reduction in $60 \mathrm{mM}$ Tris-HCl buffer (pH 6.8) containing 10\% glycerol, $2 \%$ sodium dodecyl sulfate (SDS), $100 \mathrm{mM}$ dithiothreitol (DTT) and $0.002 \%$ bromophenol blue, $50 \mu \mathrm{g}$ of protein were separated by SDS-polyacrylamide gel electrophoresis and transferred to polyvinylidene fluoride (BIO-RAD, Hercules, CA, USA) membranes. The membranes were immersed for $1 \mathrm{~h}$ in blocking buffer [5\% non-fat dry milk or 5\% bovine serum albumin (in tris-buffered saline and then incubated with primary antibodies to AKT1, AKT2, AKT3 (1:1,000; Cell Signaling, Danvers, MA, USA), or phospho-AKT (Ser473) $(1: 2,000$; Cell Signaling in Can Get Signal Solution 1 (TOYOBO, Osaka, Japan). The membranes were subsequently incubated with horseradish peroxidase-conjugated secondary antibodies in Can Get Signal Solution 2 (dilution 1:3,000; TOYOBO). The 
A

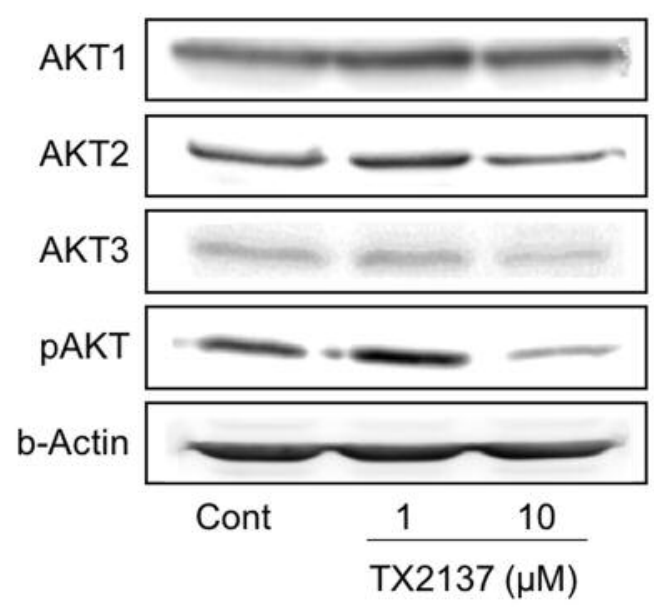

C

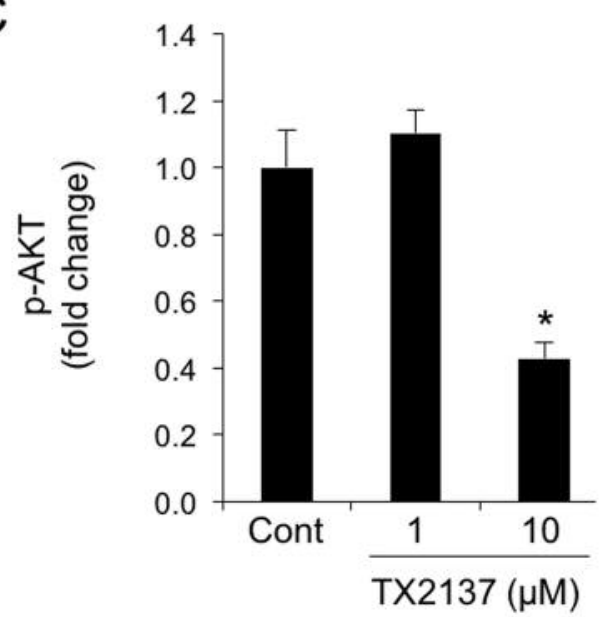

B

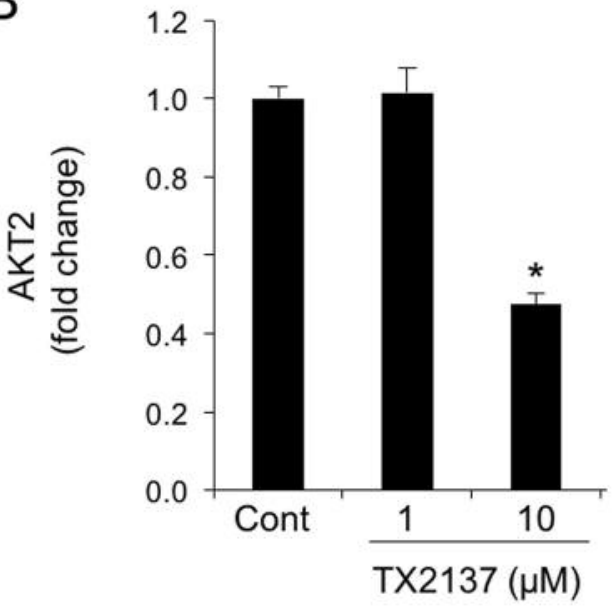

D

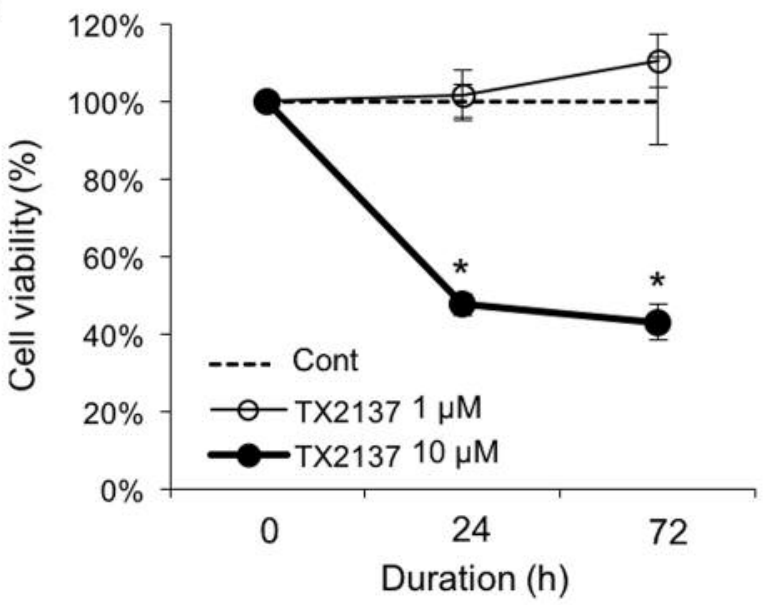

Figure 3. AKT inhibition assay of TX-2137 by western blot analysis and the cell viability in U87MG cells. Each experiment was performed four times, data are the mean \pm SD. A: Western blot analysis to detect AKT protein expression in U87MG cells. Quantitative analysis using Image J (B, $C)$ and the effect of $T X-2137$ on the cell viability of U87MG (D). Significantly different from the control at *p<0.05.

protein-antibody complexes were detected with Amersham ECL ${ }^{\circledR}$ plus (GE Healthcare, Little Chalfont, Buckinghamshire, UK) using a Lumino image analyzer (Image Quant LAS4000 mini; GE Healthcare) and NIH ImageJ 1.46 software (http://rsb.info.nih.gov/ij/). Each experiment was repeated three times.

Assay of MMP9 inhibition by TX-2137 by gelatin zymography. To analyze the effect of TX-2137 on the activation of pro-MMP2 into its activated form which is induced by MT1-MMP and on the expression and secretion of MMP2 and MMP9, HT1080 cells $\left(5 \times 10^{4}\right.$ cells $\left./ \mathrm{ml}\right)$ were seeded into a 48 -well culture plate and cultured in $100 \mu \mathrm{l}$ of complete media for $24 \mathrm{~h}$. After washing twice with serum-free DMEM, the cells were further cultured in OPTI-MEM (Invitrogen) with various concentrations of TX-2137 for $3 \mathrm{~h}$. Then, an aliquot of conditioned medium was analyzed by gelatin zymography. Zymography was performed with an $10 \%$ SDS-polyacrylamide gel containing $0.1 \%$ gelatin as described previously (19). After electrophoresis, SDS was replaced by Triton X-100, followed by overnight incubation in Trisbased buffer. Gels were stained with Coomassie Brilliant Blue, and gelatinolytic activity of MMP2 and MMP9 was detected as clear bands in a background of uniform staining.

In vivo anti-metastatic activity of TX-2137 using chick embryo model. Fertilized chicken eggs (Plymouth Rock $\times$ White Leghorn) were obtained from the Goto Chicken Farm (Gifu, Japan). The assay was performed as originally described by Endo et al. (20). Briefly, $5 \times 10^{4}$ cells were injected into the chorioallantoic membrane (CAM) veins of the chicken egg with a $30 \mathrm{G}$ needle 11 days after fertilization and eggs were incubated for a further 3 days. TX-2137 (in $0.1 \mathrm{ml}$ ) or doxorubicin (Kyowa Hakko Kirin, Tokyo, Japan) was administered into the CAM vein. Doses were as follows: $40 \mu \mathrm{g} / \mathrm{egg}$ for doxorubicin, $62.5 \mu \mathrm{g} / \mathrm{egg}$ and $125 \mu \mathrm{g} / \mathrm{egg}$ for TX-2137. After drug administration, eggs were incubated for another 4 days. Embryo livers were then dissected 7 days after tumor cell injection, and the 
total DNA was extracted. A fragment of mouse $\beta$-globin gene in the oncogene-transformed cells that colonized liver tissue was amplified by 25 cycles of polymerase chain reaction (PCR) using speciesspecific primers. Each PCR cycle consisted of $1 \mathrm{~min}$ of denaturing at $94^{\circ} \mathrm{C}, 1 \mathrm{~min}$ of annealing at $50^{\circ} \mathrm{C}$, and $1.5 \mathrm{~min}$ of extension at $72^{\circ} \mathrm{C}$. The amplified fragment ( 633 base pairs) was separated by electrophoresis in a $1.2 \%$ agarose gel. The signal intensity of the band in agarose gel was measured using image processing program Image J. Oligonucleotide primers were as follows: sense primer Mgpl (5'-GGA TCA GTT GCT CCT ACA TT-3') and antisense primer Mgp5 (5'-TAT CCG AAC TCT TGT CAA CA-3').

Statistical analysis. Data are expressed as the mean and standard deviations of at least three independent experiments. The statistical significance of the differences between the results was analyzed using Student's $t$-test. A $p<0.05$ was considered statistically significant.

\section{Results}

Design of $T X-2137$. We focused on the structural similarity of pre-existing AKT1/2 inhibitor and tirapazamine, found in the bicyclic on tirapazamine and tricyclic heteroaromatic ring of AKT1/2 inhibitor as shown by dot lines (Figure 1). We designed the simplified compound TX-2137 by removing the 1-(4-piperidyl)-2-benzimidazolinone moiety of the lead compound of the AKT1/2 inhibitor (21).

Synthesis of TX-2137. 3-Chloro-1,2,4-benzotriazine 1-oxide was synthesized using the method described by Pchalek et al. (18). Using 4-aminophenol as the starting material, the phenolic hydroxyl group was protected with tert-butylchlorodimethylsilane and coupled with 3-chloro-1,2,4-benzotriazine 1-oxide. Thereafter, the $\mathrm{N}-4$ position was oxidized to dioxide and deprotected to obtain TX-2137 (Figure 2).

Cell proliferation-inhibitory activity and hypoxic cytotoxicity of $T X-2137$. We first evaluated anti-proliferative activity and hypoxia-selective cytotoxicity of TX-2137 in different tumor cells (Table I). Table IA shows the cell proliferationinhibitory activity of TX-2137 that exhibited a strong antiproliferative effect against all the tumor cell lines tested. Table IB shows the results of the cytotoxicity assay under normoxic and hypoxic conditions. TX-2137 showed hypoxia-preferential cytotoxicity against A549 cells but the hypoxia selectivity of TX-2137 (4.2-fold) was lower than that of tirapazamine (13.1-fold).

AKT-inhibitory activity of TX-2137 on U87MG cells. We evaluated the inhibitory activity of TX-2137 on AKT protein expression, its phosphorylation and cell viability (Figure 3). TX-2137 effectively down-regulated the expression of AKT2 and the phosphorylation of AKT (Figure 3A-C). TX-2137 reduced cell viability by about $50 \%$ at $10 \mu \mathrm{M}$ after 24 and $72 \mathrm{~h}$ (Figure 3D). This result

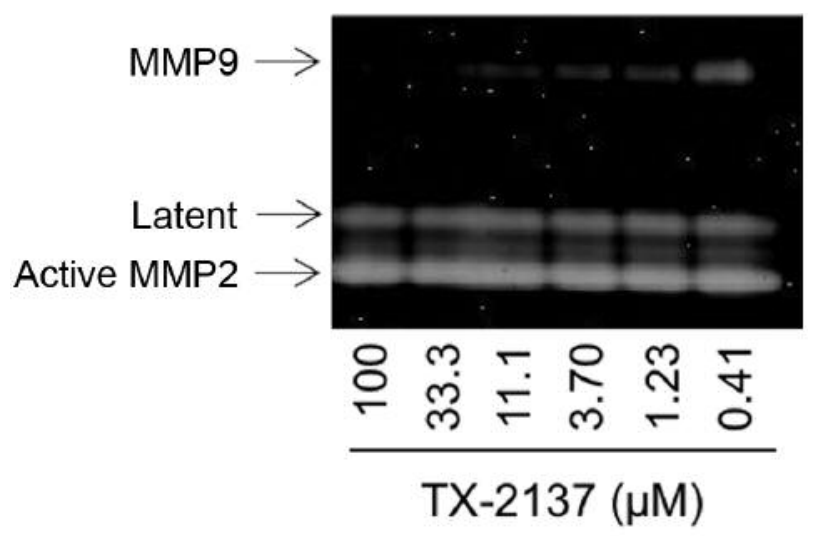

Figure 4. Effect of TX-2137 on matrix metalloproteinase 2 (MMP2) and MMP9. TX-2137 clearly inhibited expression of MMP9 in a concentration-dependent manner.

correlates with the inhibition of AKT2 expression and AKT phosphorylation by TX-2137.

Inhibitory activity of TX-2137 on MMP9 production in HT1080 cells. The inhibitory activity of TX-2137 on MMP9 production was evaluated by zymographic assay using HT-1080 cells. TX-2137 inhibited the production of MMP9, but did not alter MMP2 production and activation (Figure 4).

Anti-metastatic activity of TX-2137 using chick embryo model on B16-F10 cells. Anti-metastatic activity of TX-2137 was assayed using a xenograft model using chick embryo. TX-2137 effectively prevented liver metastasis of B16-F10 melanoma cells in the same way as doxorubicin (Figure 5).

\section{Discussion}

In this study, we designed and synthesized TX-2137, which is a novel anti-metastatic hypoxic cytotoxin with AKT inhibitory activity, and evaluated its antitumor and anti-metastatic activities using in vitro and in vivo assay systems. TX-2137 showed strong anti-proliferative activity against tumor cell lines, with $\mathrm{IC}_{50}$ values ranging from 1.8 to $3.7 \mu \mathrm{M}$. Hypoxiaselective activity of TX-2137, however, was lower than that of tirapazamine. TX-2137 showed potent cytotoxicity even under normoxic conditions and little difference was observed compared to hypoxic conditions owing to its higher electron affinity compared to tirapazamine as shown in Figure 1. However, TX-2137 is susceptible to reduction and its reduced form may be highly cytotoxic due to hydroxyl radical production even under normoxic conditions. TX-2137 selectively down-regulated the expression of AKT2 protein and phosphorylation of AKT; these findings indicate that the 1-(4-piperidyl)-2-benzimidazolinone moiety of AKT1/2 inhibitor is not essential for its activity. 

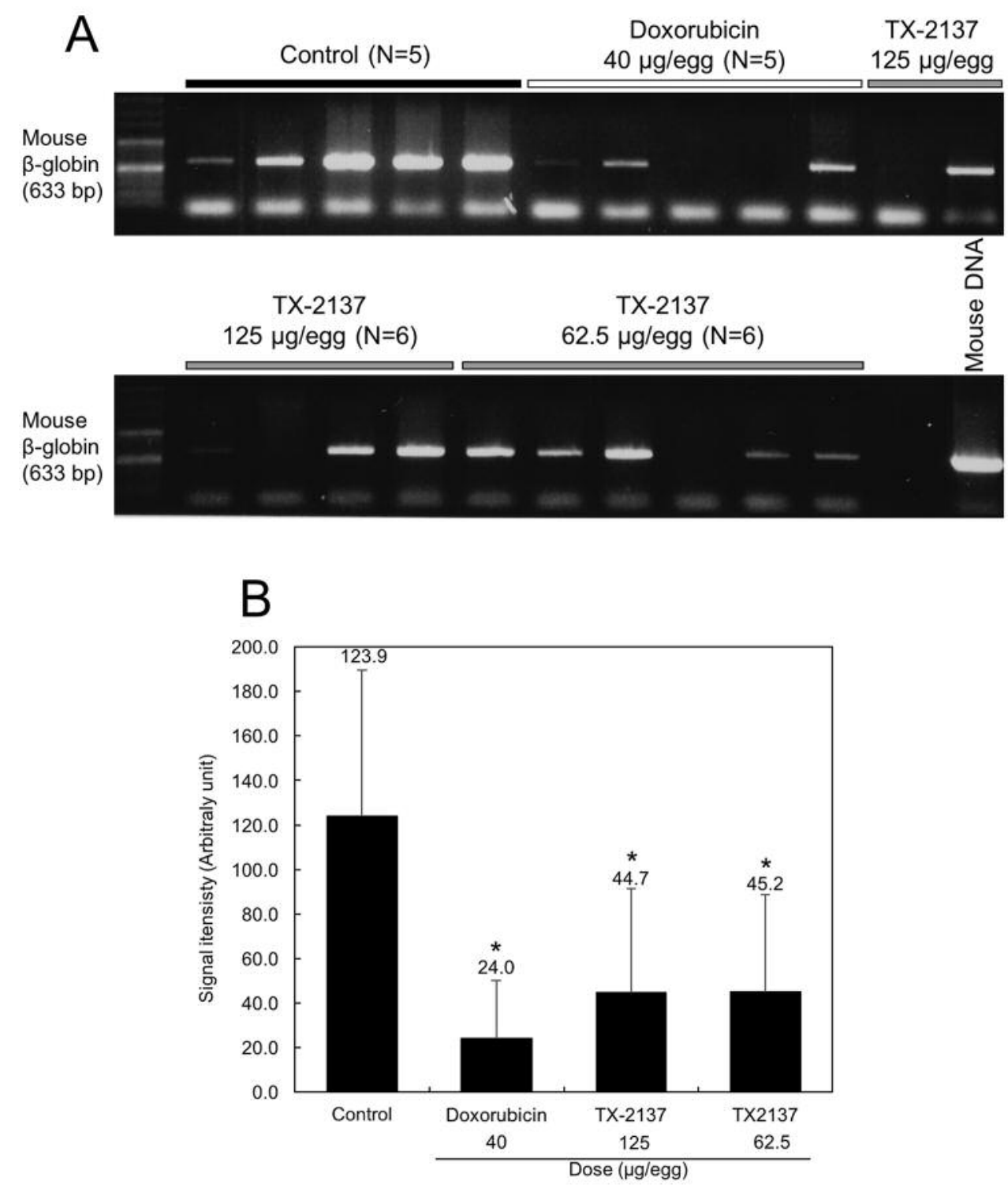

Figure 5. Evaluation of anti-metastatic activity of TX-2137 using the chick embryo model. Polymerase chain reaction analysis to detect liver metastases of B16-F10 melanoma (A) and quantitative analysis of the signal intensity shown in (A) using the Image J software (B). Treatment with $T X-2137$ and doxorubicin led to significantly lower signal intensities than that of the control $\left({ }^{*} p<0.05\right)$.

MMP9, which is a downstream target of the AKT signaling pathway, plays an important role in invasion and metastasis of various cancer types, and MMP9 has been shown to be an important molecular target for the suppression of cancer metastasis (22). HT-1080 human fibrosarcoma cells were derived from a highly metastatic tumor and produce various MMPs including MMP2, MMP3, MMP9, and MMP14/MT1MMP $(23,24)$. HT-1080 cells were shown to metastasize in xenograft models using nude mouse (25) and chick embryo (26-28). In the MMP-inhibitory assay here, TX-2137 inhibited MMP9 production in HT-1080 cells. Next, we evaluated the anti-metastatic activity of TX-2137 by using the chick embryo model because the chick embryo model provides a costeffective, easily-accessible and rapid approach $(29,30)$. In this xenograft model, TX-2137 showed strong anti-metastatic activity against liver metastasis of B16-F10 melanoma.

From this study, TX-2137 appears to exhibit strong antimetastatic activity through inhibition of AKT expression and phosphorylation, and suppression of MMP9 production.

In conclusion, we succeeded in the development of the anti-metastatic hypoxic cytotoxin TX-2137 possessing the inhibitory activity of AKT expression and MMP9 production. 


\section{References}

1 Collet G, Szade K, Nowak W, Klimkiewicz K, El Hafny-Rahbi B and Szczepanek K, Sugiyama D, Weglarczyk K, FoucaultCollet A, Guichard A, Mazan A, Nadim M, Fasani F, Lamerant FN, Grillon C, Petoud S, Beloeil JC, Jozkowicz A, Dulak J and Kieda C: Endothelial precursor cell-based therapy to target the pathologic angiogenesis and compensate tumor hypoxia. Cancer Lett 370: 345-357, 2016.

2 Gilkes DM, Semenza GL and Wirtz D: Hypoxia and the extracellular matrix: drivers of tumour metastasis. Nat Rev Cancer 14: 430-439, 2014.

3 Graeber TG, Osmanian C, Jacks T, Housman DE, Koch CJ, Lowe SW and Giaccia AJ: Hypoxia-mediated selection of cells with diminished apoptotic potential in solid tumours. Nature 379: 88-91, 1996.

4 Muz B, de la Puente P, Azab F and Azab AK: The role of hypoxia in cancer progression, angiogenesis, metastasis, and resistance to therapy. Hypoxia Auckl 3: 83-92, 2015.

5 Lee C, Siu A and Ramos DM: Multicellular spheroids as a model for hypoxia-induced EMT. Anticancer Res 36: 6259-6263, 2016.

6 Hwang JT, Greenberg MM, Fuchs T and Gates KS: Reaction of the hypoxia-selective antitumor agent tirapazamine with a $\mathrm{C} 1$ 'radical in single-stranded and double-stranded DNA: The drug and its metabolites can serve as surrogates for molecular oxygen in radical-mediated DNA damage reactions. Biochemistry 38: 14248-14255, 1999.

7 Brown JM and Wilson WR: Exploiting tumor hypoxia in cancer treatment. Nat Rev Cancer 4: 437-447, 2004.

8 Yin J, Glaser R and Gates KS: Electron and spin-density analysis of tirapazamine reduction chemistry. Chem Res Toxicol 25: 620-633, 2012.

9 Rischin D, Peters L, Fisher R, Macann A, Denham J, Poulsen M, Jackson M, Kenny L, Penniment M, Corry J, Lamb D and McClure B: Tirapazamine, cisplatin, and radiation versus fluorouracil, cisplatin, and radiation in patients with locally advanced head and neck cancer: A randomized phase II trial of the Trans-Tasman Radiation Oncology Group (TROG 98.02). J Clin Oncol 23: 79-87, 2005.

10 Williamson SK, Crowley, JJ, Lara PN Jr, McCoy J, Lau DH, Tucker RW, Mills GM and Gandara DR; Phase III trial of paclitaxel plus carboplatin with or without tirapazamine in advanced non-small-cell lung cancer: Southwest Oncology Group Trial S0003. J Clin Oncol 23: 9097-9104, 2005.

11 Rischin D, Peters LJ, O’Sullivan B, Giralt J, Fisher R, Yuen K, Trotti A, Bernier J, Bourhis J, Ringash J, Henke M and Kenny L: Tirapazamine, cisplatin, and radiation versus cisplatin and radiation for advanced squamous cell carcinoma of the head and neck (TROG 02.02, HeadSTART): A phase III trial of the Trans-Tasman Radiation Oncology Group. J Clin Oncol 28: 2989-2995, 2010.

12 Agarwal E, Brattain MG and Chowdhury S: Cell survival and metastasis regulation by AKT signaling in colorectal cancer. Cell Signal 25: 1711-1719, 2013.

13 King D, Yeomanson D and Bryant HE: PI3King the Lock: targeting the PI3K/AKT/mTOR pathway as a novel therapeutic strategy in neuroblastoma. J Pediatr Hematol Oncol 37: 245-251, 2005.

14 Almhanna K, Strosberg J and Malafa M: Targeting AKT protein kinase in gastric cancer. Anticancer Res 31: 4387-4392, 2011.

15 Mayer IA and Arteaga CL: The PI3K/AKT pathway as a target for cancer treatment. Annu Rev Med 67: 11-28, 2016.
16 Chae YC, Vaira V, Caino MC, Tang HY, Seo JH, Kossenkov AV, Ottobrini L, Martelli C, Lucignani G, Bertolini I, Locatelli M, Bryant KG, Ghosh JC, Lisanti S, Ku B, Bosari S, Languino LR, Speicher DW and Altieri DC: Mitochondrial AKT regulation of hypoxic tumor reprogramming. Cancer Cell 30: 257-272, 2016.

17 Hay MP, Gamage SA, Kovacs MS, Pruijn FB, Anderson RF, Patterson AV, Wilson WR, Brown JM and Denny WA: Structure-activity relationships of 1,2,4-benzotriazine 1,4dioxides as hypoxia-selective analogues of tirapazamine. J Med Chem 46: 169-182, 2003.

18 Pchalek K and Hay MP: Stille coupling reactions in the synthesis of hypoxia-selective 3-alkyl-1,2,4-benzotriazine 1,4dioxideanticancer agents. J Org Chem 71: 6530-6535, 2006.

19 Sato H, Takino T, Okada Y, Cao J, Shinagawa A, Yamamoto E and Seiki M: A matrix metalloproteinase expressed on the surface of invasive tumor cells. Nature 370: 61-65, 1994.

20 Endo Y, Seiki M, Uchida H, Noguchi M, Kida Y, Sato H, Mai M and Sasaki T: Experimental metastasis of oncogene-transformed NIH 3T3 cells in chick embryo. Jpn J Cancer Res 83: 274-280, 1992.

21 Lindsley CW, Zhao Z, Leister WH, Robinson RG, Barnett SF, Defeo JD, Jones RE, Hartman GD, Huff JR, Huber HE and Duggan ME: Allosteric AKT (PKB) inhibitors: discovery and SAR of isozyme selective inhibitors. Bioorg Med Chem Lett 15: 761-764, 2005.

22 Itoh T, Tanioka M, Matsuda H, Nishimoto H, Yoshioka T, Suzuki $\mathrm{R}$ and Uehira M: Experimental metastasis is suppressed in MMP9-deficient mice. Clin Exp Metastasis 17: 177-181, 1999.

23 Sato H, Kida Y, Mai M, Endo Y, Sasaki T, Tanaka J and Seiki M: Expression of genes encoding type IV collagen-degrading metalloproteinases and their inhibitor TIMPs in various human tumor cells. Oncogene 7: 77-83, 1992.

24 Abd El-Aziz SH and Endo Y, Miyamaori H, Takino T and Sato H: Cleavage of growth differentiation factor 15 (GDF15) by membrane type 1-matrix metalloproteinase abrogates GDF15-mediated suppression of tumor cell growth. Cancer Sci 98: 1330-1335, 2007.

25 Ohta Y, Watanabe Y, Tabata T, Oda M, Hayashi Y, Endo Y, Tanaka $\mathrm{M}$ and Sasaki T: Inhibition of lymph node metastasis by an antiangiogenic agent, TNP-470. Br J Cancer 75: 512-515, 1997.

26 Endo Y, Sasaki T, Harada F and Noguchi M: Specific detection of metastasized human tumor cells in embryonic chicks by the polymerase chain reaction. Jpn J Cancer Res 81: 723-726, 1990.

27 Tsuchiya Y, Endo Y, Sato H, Okada Y, Mai M, Sasaki T and Seiki M: Expression of type IV collagenases in human tumor cell lines that can form liver colonies in chick embryo. Int $\mathbf{J}$ Cancer 56: 46-51, 1994.

$28 \mathrm{Li} \mathrm{Z}$, Takino T, Endo Y and Sato H: Activation of matrix metalloproteinase (MMP)-9 by membrane-type-1 matrix metalloproteinase/MMP2 axis stimulates tumor metastasis. Cancer Sci 108: 347-357, 2017.

29 Wilson SM and Chambers AF: Experimental metastasis assays in the chick embryo. Curr Protoc Cell Biol 19: 19.6, 2004.

30 Uto Y, Tamatani D, Mizuki Y, Endo Y, Nakanishi I, Ohkubo K, Fukuzumi S, Ishizuka M, Tanaka T, Kuchiike D, Kubo K, Inui $\mathrm{T}$ and Hori $\mathrm{H}$ : Evaluation of the sonosensitizing activities of 5aminolevulinic acid and Sn(IV) chlorine 6 in tumor-bearing chick embryos. Anticancer Res 34: 4583-4587, 2014.

Received May 2, 2017

Revised May 24, 2017

Accepted May 29, 2017 